------ Iraqi Journal of Earth Sciences, Vol. 9, No. 2, pp. ऍq_々^, 2009 ------

\title{
Pollution Caused by Vehicle Exhausts and Oil Trash Burning in Kirkuk city
}

\author{
Farhad A. Mohammed \\ Department of Geology \\ College of Science \\ Salahaddin University
}

(Received $7 / 11 / 2008$, Accepted $r \wedge / 1 / 2009$ )

\begin{abstract}
This study included the collection and analyses of twenty six soil samples, (twenty one samples) from dust residing on the main streets of Kirkuk city, and the remaining five were collected from different localities of older deposits which covered the ancient Kirkuk citadel.

The analyses showed that there are an increase in the concentrations of Lead $(\mathrm{pb})$, Cadmium $(\mathrm{Cd})$, Copper $(\mathrm{Cu})$ and Zinc $(\mathrm{Zn})$ in the dust specimens. These elements regarded as polluting materials in the environment when compared with the natural limits of their concentrations in soil. The analyses of dust specimens showed an increase of the concentration of these elements when compared with those collected from older deposits covering the ancient Kirkuk citadel. This is due to heavy traffic and burning of petroleum trash in this city.Vehicle exhausts are the main source of high concentration of these elements, as well as the presence of Northern Oil Company in Kirkuk city.Fuel burning causes disorder in the concentration of these elements in different environments, thus reaching the human body via air, water and food.
\end{abstract}

\section{التلوث الناجم عن عوادم السيارات و الفضلات النفطية المحروقة في مدينة كركوك}

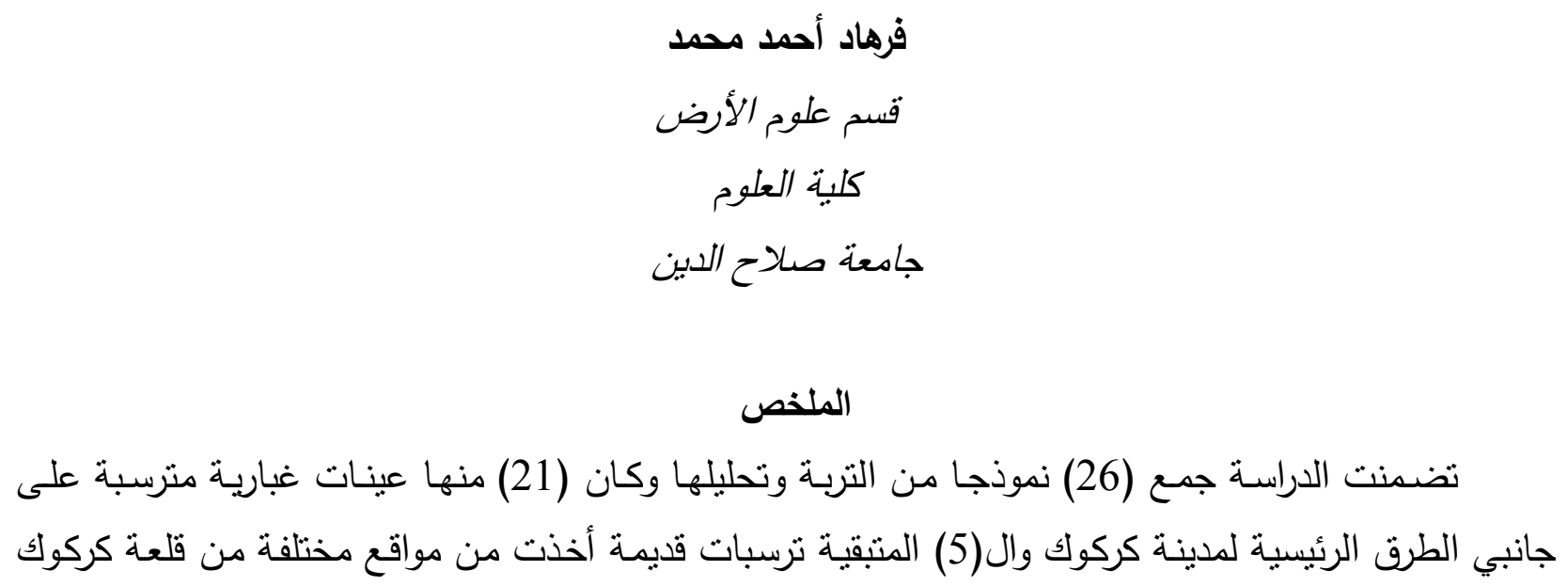


الأثربـة وتبـين إنها تحتوي على نسـبة عاليـة مـن عناصـر الرصـاص (Pb) وكـادميوم (Cd) والنحساس (Cu) والخارصين (Zn) عند مقارنتها بحدود تواجدها الطبيعي في التربة وعليه يمكن اعتبارها عناصر ملوثة للبيئة. تبين من تحليلات هذه النماذج بأن هناك زيادة في تراكيز العناصر المذكورة مقارنـة بالعينات التي جمعت من

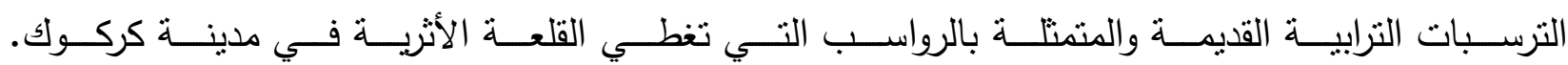
و يعزى السبب في ذلك الى زيادة الكثافة المرورية في هذه الشوارع حيث تعد السيارات المصادر الرئيسية لهذه العناصر ، بالإضافة إلى أسباب أخرى منها طبيعة نواجد المصادر النفطية في هذه المدينة واحتراق فضلاتها من قبل شركة نفط الشمال على شكل عدد كبير من المحارق النارية موزعة في أماكن مختلفة. حيث يؤدي حرق هـث الوقود الى احداث خلل في مستوى تراكيز هذه العناصر في مختلف البيئات وبالتالي وصولها إلى جسم الإنسان بطرق مختلفة من الهواء والماء والغذاء.

\section{INTRODUCTION}

Some trace elements are necessary to human health to carry out living activities, but these elements can rapidly become toxic if their concentrations increase above the allowed limits (Faure, 1998).

In recent years, there is an increased interest to analyze trace elements in human materials like foods, drinking water and air, so as to understand the relation of these elements with the living systems in human body, especially the elements that have different toxic effects on environment (Sharaf, 1986).

Some chemical elements in different organic materials whether of animal or plant are regarded as a Macro Essential Elements like: [Cl, $\mathrm{P}, \mathrm{N}, \mathrm{Ca}, \mathrm{Mg}, \mathrm{K}, \mathrm{Na}, \mathrm{O}, \mathrm{H}$ and $\mathrm{C}$ ] whereas others are regarded as a Micro Essential Elements like: Cobalt (Co), Chromium $(\mathrm{Cr})$, Copper $(\mathrm{Cu})$, Iodine (I), Manganese (Mn), Molybdenum (Mo), Vanadium (V), Zinc $(\mathrm{Zn})$, Iron $(\mathrm{Fe})$, Flour $(\mathrm{F})$, and Nickel $(\mathrm{Ni})$. These elements convert toxic if their concentrations increase above the allowed limits, (Fig.1).

The third type of elements are not essential but they are originally toxic like: Cadmium $(\mathrm{Cd})$, Lead $(\mathrm{Pb})$, Mercury $(\mathrm{Hg})$, Beryllium (Be), Thallium (Th), Arsenic (As), Barium (Ba) and Antimony (Sb) (Fergusson, 1982).

In this study, two elements $\mathrm{Cu}$ and $\mathrm{Zn}$ are from Micro Essential Elements which are converted to toxic elements when there concentrations increase above the allowed limits, while other two elements $\mathrm{Pb}$ and $\mathrm{Cd}$ which are originally toxic, were studied in the fallen dust.

These two elements are necessary for defending human environment from pollution and consequently, it is essential to keep their concentration limits fixed in this environment (Montgomery, 1997).

The elements $\mathrm{Pb}, \mathrm{Cd}, \mathrm{Cu}$, and $\mathrm{Zn}$ are pollutant because of their effects on health and diffusion in environment more than other elements ( WHO - 1979 ). Kirkuk city is located between latitudes (35 - 36$) \mathrm{N}$ and longitudes (143 - 145 ) E north Iraq (Fig.2). 
Twenty one samples of dust resident on the main streets of the city and five samples of the older deposits at the ancient Kirkuk citadel were collected. The aim of this study is to determine the extent of concentrations of $\mathrm{Pb}, \mathrm{Cd}, \mathrm{Cu}$ and $\mathrm{Zn}$.

All of samples were analyzed by Atomic Absorption Spectrometer type. (Shimadzu A.A.-6200) at Kirkuk Agriculture Directorate.

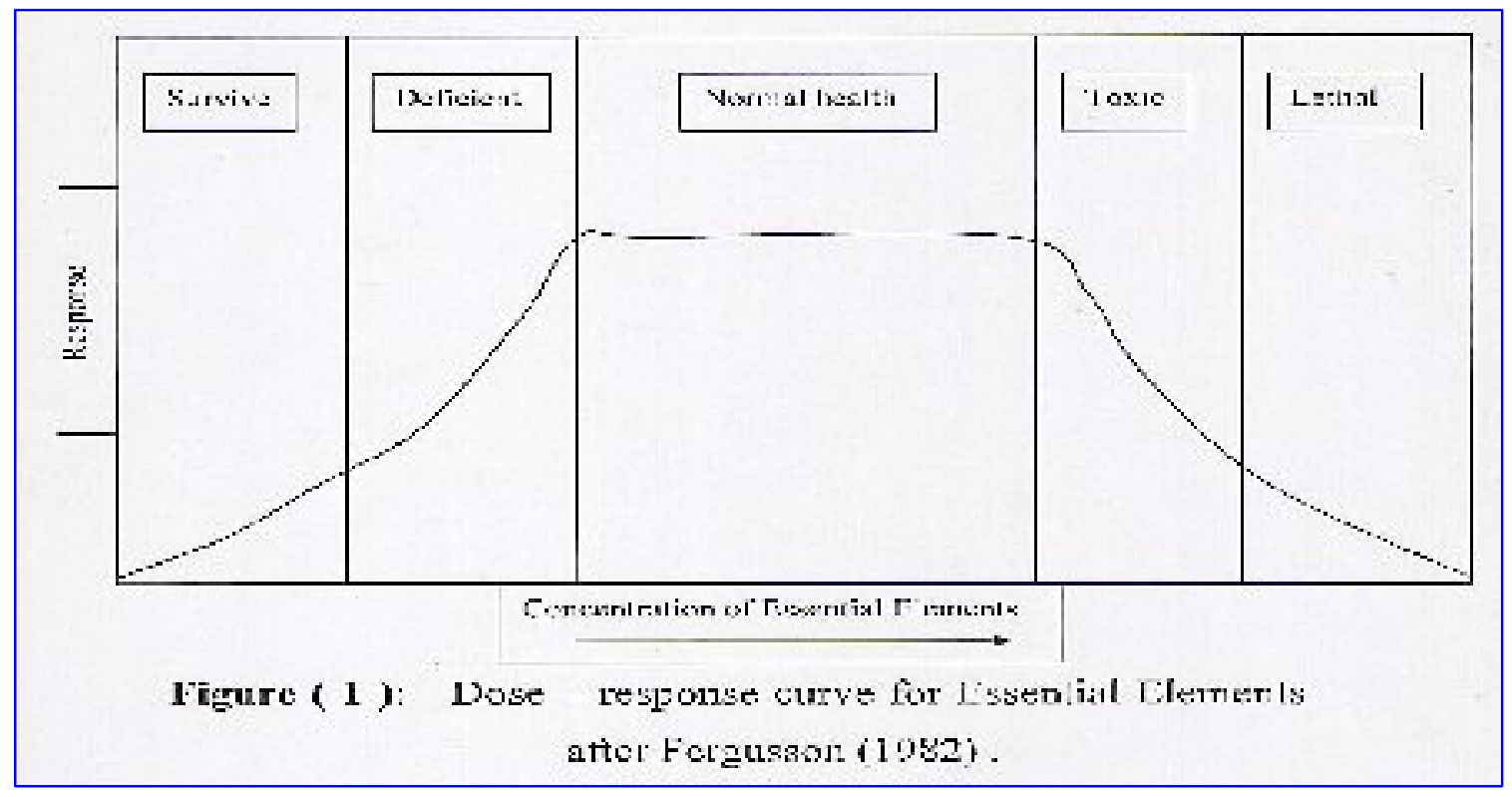

Fig. 1 :Dose-response curve for Essential Elements after Fergusson (1982).

Al-Awadat and Basshy (1990) determined the quantity and quality of falling dust on the area of Riyadh city in Saudi Arabia and found that there were surplus of concentration of $\mathrm{Pb}$ and As in this area. Othman and Sabra (1991) tested the falling dust on Damascus city in Syria and studied the pollutant elements like $\mathrm{Pb}, \mathrm{Cu}$, and $\mathrm{Zn}$ on tree leaves and found that the concentrations were ( $108 \mathrm{ppm}, 52 \mathrm{ppm}$, and $16 \mathrm{ppm}$ ) respectively due to heavy traffic in Damascus.

Al-Sayegh and Al- Mofty (1999) evaluated the environmental pollution of Tigris River recent sediments and determined how to stable some chemical elements entering human body via drinking water in Mousl city.

Al-Barzinjy (2000) evaluated some trace elements in gall stones of patients from middle and north Iraq and related these elements with environment, and concluded that elements like $\mathrm{pb}, \mathrm{Cd}$, and $\mathrm{Zn}$ have direct relation with old patients.

Al-Sayegh and Al-Yazichi (2001) studied pollution environment caused by car exhausts in Mousl city and found that there are an increase in the concentrations of $\mathrm{Pb}, \mathrm{Cd}$, $\mathrm{Cu}$, and $\mathrm{Zn}$ in dust specimens resident on the main streets of Mousl city.

Ismail (2004) determined atmospheric pollution and environmental effects in Kirkuk area; he demonstrated that precipitation has acidic characteristics within the normal limits, due to the presence of oil industrial activities and automobile exhausts in Kirkuk city. 


\section{SAMPLING AND ANALYSES PROCEDURE}

Twenty six soil samples of which (21) samples are dust specimen deposits on the main streets of Kirkuk city, and (5) on older deposits collected at $(10 \mathrm{~cm})$ depth in different localities of the ancient Kirkuk citadel were collected, using Soil Auger. Samples were analyzed for the elements $(\mathrm{Pb}, \mathrm{Cd}, \mathrm{Cu}$, and $\mathrm{Zn})$. using (Al-Kufaishy, 1975) procedure by Atomic Absorption Spectrometer type (Shimadzu A .A .- 6200) at Kirkuk Agriculture Directorate ( 2008 ).

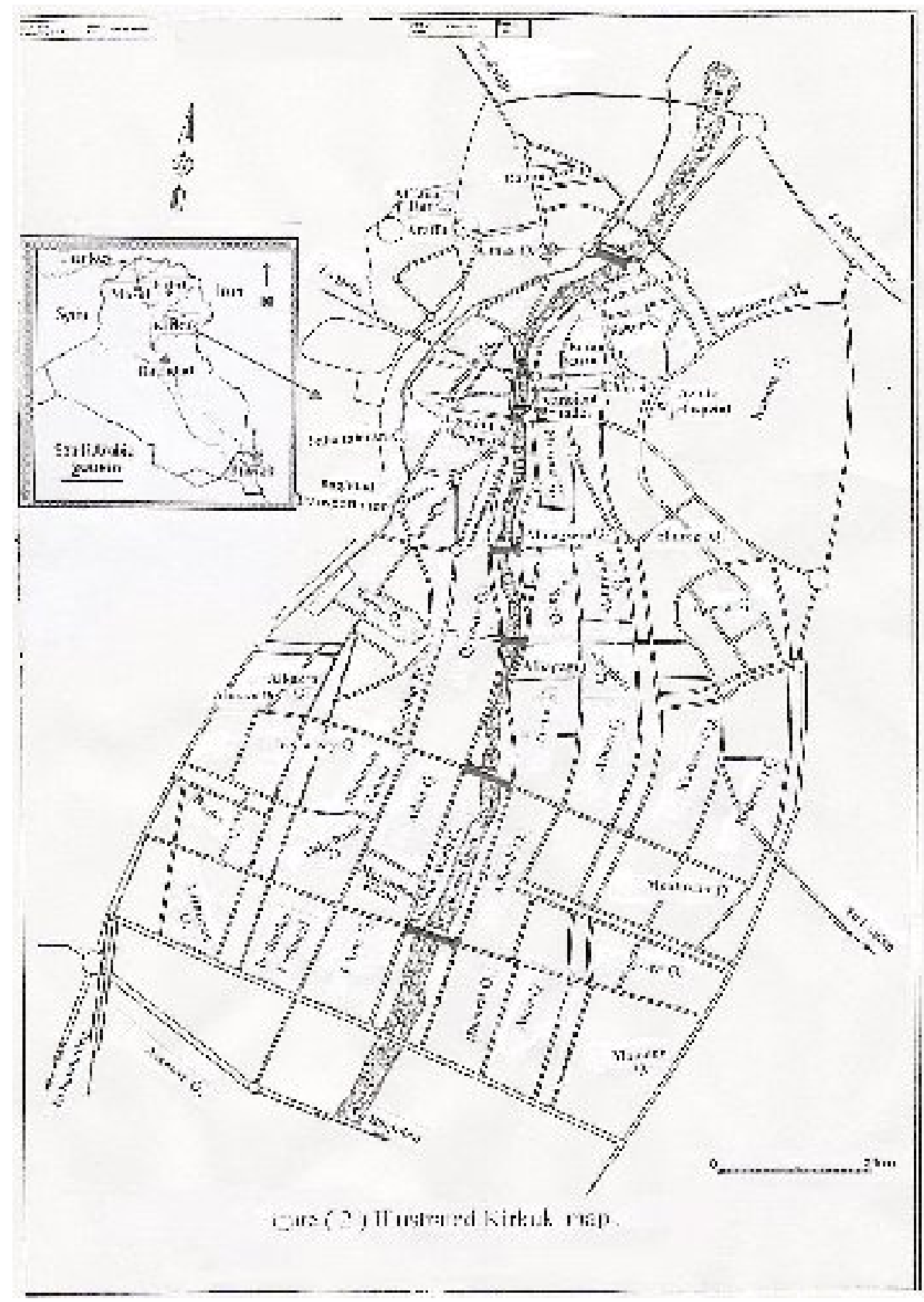

Fig. 2 :Illustrated Kirkuk map 


\section{RESULTS AND DISCUSSION}

Table(1) shows the concentration of the Pollutant elements in the dust samples resident on the main streets of Kirkuk city and the older deposits of the ancient Kirkuk citadel.

\section{Lead (Pb)}

Lead is a pollutant element that can cause some diseases and toxic state if human exposed to high doses (WHO, 1985), or its concentration is more than allowed limit may cause some health problems to human . The allowed limit of $\mathrm{Pb}$ is $(0.05 \mathrm{mlg} / \mathrm{L})$ or $120 \mathrm{mg}$ in human body (70) Kg of weight (Al- Sayegh and Al- Yazichi 2001) .

Lead is one of the seven elements that accompanied human civilization since primitive man kind and was mentioned in many ancient references, ex. Ebocrat referred to toxicities by $\mathrm{Pb}$ in about 370 B.C. (Ommer, 2000 ).

The concentration of this element in dust specimens ranges between $(107-840)$ ppm with an average of (412) ppm, while its concentration in deposits of ancient Kirkuk citadel samples ranges between ( $21-72$ ) ppm with an average of ( 45 )ppm (Table 1). It is evident that the concentration of this element is high in specimens of heavy traffic streets, like ( Rahim Awa Q., Algmhoria st., Baghdad st., Araffa Q., Saha taiaran Q.).

Even higher concentrations were observed specially in areas to the west of Kassa River in the city like (Rahim Awa Q., Araffa Q., Saha taiaran Q., Baghdad Transport station, Almaarth Q., Sinaai Q.).

Table (2) shows the average concentrations of $(\mathrm{pb}),(\mathrm{Cd}),(\mathrm{Cu})$, and $(\mathrm{Zn})$ in the Studied specimens compared with some similar Previous Studies.

The surplus of $(\mathrm{Pb})$ is due to the temporarily accumulated lead in dust specimens resident on the main streets of Kirkuk city resulting from vehicle exhausts and oil trash burns Northern Oil Company, in addition to some chemical materials like Lead tetra ethelate $\left(\mathrm{C}_{2} \mathrm{H}_{5}\right)_{4} \mathrm{~Pb}$ added to benzene for improving combustion activity (Ali, 1987; Ommer, 2000). Another reason is the addition of favorable amount of ethelyne chlorite $\left(\mathrm{C}_{2} \mathrm{H}_{4} \mathrm{Cl}_{2}\right)$ and ethelyne bromide $\left(\mathrm{C}_{2} \mathrm{H}_{4} \mathrm{Br}\right)$ to convert lead in benzene in the course of combustion to the favorable material lead bromide $\left(\mathrm{Pb} \mathrm{Br}_{2}\right)$ which is evaporated with car exhausts to air and then resides on soil (Al- Sayegh and Al-Yazichi, 2001). 
Table 1: Concentrations of $\mathrm{Pb}, \mathrm{Cd}, \mathrm{Cu}$, and $\mathrm{Zn}$ in samples of present study .

\begin{tabular}{|c|c|c|c|c|c|}
\hline \multirow[t]{2}{*}{ Sample No. } & \multirow[t]{2}{*}{ Locations } & \multicolumn{3}{|c|}{ Elements(ppm) } & \\
\hline & & $\mathrm{Zn}$ & $\mathrm{Cu}$ & $\mathrm{Cd}$ & $\mathrm{Pb}$ \\
\hline 1 & Rahim Awa Q. & 211 & 316 & 4 & 840 \\
\hline 2 & Araffa Q. & 1015 & 125 & 3 & 638 \\
\hline 3 & Algmhoria st. & 901 & 165 & 2 & 700 \\
\hline 4 & Saha taiaran Q. & 675 & 158 & 1 & 671 \\
\hline 5 & Algmhoria Hospital st. & 513 & 125 & 4 & 312 \\
\hline 6 & Baghdad transport station & 711 & 171 & 7 & 511 \\
\hline 7 & Baghdad st. & 705 & 292 & 1 & 701 \\
\hline 8 & Tsen Q. & 401 & 124 & 1 & 360 \\
\hline 9 & Almaarth Q. & 701 & 129 & 2 & 416 \\
\hline 10 & wasty Q. & 315 & 79 & 0.5 & 260 \\
\hline 11 & Madena Alaab Q. & 402 & 131 & 1 & 311 \\
\hline 12 & Snaai Q. & 921 & 261 & 4 & 673 \\
\hline 13 & Eskan Q. & 517 & 130 & 0.3 & 310 \\
\hline 14 & Sulaemanea st. & 411 & 136 & 0.5 & 218 \\
\hline 15 & Mossala Q. & 507 & 127 & 1 & 370 \\
\hline 16 & Shorega Q. & 434 & 141 & 1.5 & 261 \\
\hline 17 & Horea Q. & 511 & 130 & 0.3 & 107 \\
\hline 18 & Oroba Q. & 370 & 79 & 0.6 & 216 \\
\hline 19 & Kadsea / 2 Q. & 460 & 175 & 0.5 & 251 \\
\hline 20 & Zaora Q. & 449 & 112 & 0.3 & 270 \\
\hline 21 & Rashed (Domez) Q. & 315 & 85 & 0.3 & 210 \\
\hline Average & & 545 & 152 & 1.68 & 412 \\
\hline 22 & $\begin{array}{l}\text { Kirkuk } \\
\text { citadel(SouthRidge) }\end{array}$ & 110 & 52 & 0.3 & 61 \\
\hline 23 & $\begin{array}{l}\text { Kirkuk } \\
\text { citadel(NorthRidge) }\end{array}$ & 115 & 67 & 0.5 & 60 \\
\hline 24 & $\begin{array}{l}\text { Kirkuk citadel (East } \\
\text { Ridge) }\end{array}$ & 95 & 48 & N.d & 21 \\
\hline 25 & $\begin{array}{l}\text { Kirkuk citadel } \\
\text { (WestRidge) }\end{array}$ & 114 & 70 & 1.2 & 72 \\
\hline 26 & Kirkuk citadel ( Center ) & 96 & 63 & 0.5 & 31 \\
\hline Average & & 106 & 60 & 0.5 & 45 \\
\hline
\end{tabular}

N.d = Not detected 
Table 2: Average concentrations of some pollutant elements (ppm) of this study compared with other areas.

\begin{tabular}{|c|c|c|c|c|}
\hline Elements & $\begin{array}{c}\text { Al-Sayegh } \\
\text { and Al-Yazichi } \\
(2001) \\
\mathrm{n}=22\end{array}$ & $\begin{array}{c}\text { Othman and } \\
\text { Sabra (1991) }\end{array}$ & $\begin{array}{c}\text { Ancient Kirkuk } \\
\text { citadel deposits } \\
\text { Present study } \\
\mathrm{n}=5\end{array}$ & $\begin{array}{c}\text { Dust specimens of } \\
\text { Present study }\end{array}$ \\
\hline $\mathrm{Pb}$ & 440 & 163 & 45 & $\mathrm{n}=21$ \\
\hline $\mathrm{Cd}$ & 11 & ---- & 0.5 & 1.68 \\
\hline $\mathrm{Cu}$ & 170 & 52 & 60 & 152 \\
\hline $\mathrm{Zn}$ & 757 & 108 & 106 & 545 \\
\hline
\end{tabular}

\section{Cadmium ( Cd )}

Cadmium is one of the elements that has temporarily nature when accumulated in human body and remains for a long time before it exposes toxic effects. However, if increase its rate in human body higher than the allowed limit it rapidly affects the kidneys, central nerve system, anemia, and impotency and causes infertility Emsely, 1998; Al-Barzinjy 2000 ).

In late years, it is observed that humans who died from hypertension carried high amount of cadmium in there kidneys. (Al-Sayegh and Al-Taka 2002).

In the present study concentration of this element in dust specimens ranged between $(0.1-7) \mathrm{ppm}$ with an average of (1.68) ppm, while its concentration in deposits of ancient citadel samples ranged between ( N.d - 1.2) ppm with an average of ( 0.5 ) ppm (Table 1).

The concentration of this element is high in specimens from streets of heavy traffic, like (Rahim Awa Q., Algmhoria Hospital st., Baghdad Transport station, hay Snaai Q.), compared with the sample deposits of the ancient Kirkuk citadel.

\section{Copper (Cu)}

Copper is an important element in human body as it enters in blood composition. Human body needs this element daily for blood cell construction, but if exceeds the natural limit (100) mg per (70) $\mathrm{kg}$ (Weight of normal human ), it converts to hazardous element and causes more diseases like Liver disease (Al-Sayegh and Al-yazichi, 2001).

Copper is a widespread element in nature (Emsely, 1998), it passes to human body through food rich in $\mathrm{Cu}$ like vegetable leaves (chard which contains (25) ppm $\mathrm{Cu}$ depending on the concentration in soil types). In meat specially liver and kidney, there is $(200-400)$ ppm (Adriano, 1986). Increased rate of copper in environments affects plants and human directly or indirectly (WHO, 1982 ). 
In the present study copper in dust specimens ranges between ( $79-316)$ ppm with an average of (152 )ppm, while concentration of this element in deposits of ancient Kirkuk citadel samples ranges between (48 -70) ppm with an average of ( 60 )ppm (Table 1).

Copper concentration increases in ( Rahim Awa Q., Baghdad st. , Snaai Q.). due to heavy traffic and oil trash burns of Northern oil Company, while there is low concentration in deposits covering the ancient Kirkuk citadel (Tables 1 and 2).

\section{Zinc (Zn )}

Zinc represents another important element for human body if present as small amounts associated in composition of constriction members like skin, liver, kidneys, reproductive system and affects wound healing (Adriano, 1986).

Zinc is not an accumulating element therefore shows slow toxicity (Al Omer, 2000), but it converts to a hazardous element if exceeds the allowed limit.

In the present study, the concentration of this element in dust specimens ranges between $(211$ - 1015) ppm with an average of (545) ppm, whereas, in the ancient deposits ranges between ( $95-115$ ) ppm with an average of ( 106 )ppm (Table 1). It has a high average in dust specimens compared with that of ancient Kirkuk citadel specimens, or those in previous studies (Table 2).

\section{CONCLUSIONS}

1- Total chemical analyses show that there is higher concentrations of pollutant elements $\mathrm{Pb}, \mathrm{Cd}, \mathrm{Cu}$, and $\mathrm{Zn}$ in specimens resident on the main streets of Kirkuk city in comparison with specimens of older deposits covering the ancient Kirkuk citadel.

2- The chemical analyses of polluting elements show that there are higher concentrations in samples collected from the western side of Kassa River in comparisons with those collected from the eastern side of the river. This is due to heavy traffic near western side of the river and also being close to the Northern Oil Company.

\section{RECOMMENDATIONS}

This study recommends the following:

1- Daily or periodical removal of dust resident on the brinks of streets that contains surplus Vehicle exhausts, which are suspended in air.

2- Carrying out environmental studies to diagnose the related diseases, in addition to testing and measuring of soil, water, and air pollution periodically.

3- Lowering heavy traffic in main streets of Kirkuk city, by implementing environmental vehicles or increasing highways and bridges.

4- Burning fuel surplus from the Northern Oil Company in air must be utilized in producing materials like (plasters from burnt gypsum) which are present in Kirkuk city.

5- The improvement of the quality of car fuels to reduce the concentration of $\mathrm{Pb}$. 
6- Green belts in Kirkuk city must be increased to decrease dusts and polluting gases in the atmosphere.

7-Treatment instead of burning of wastes of Kirkuk municipality, specially dumps which are close to mountain series located to east and north east of this city.

\section{REFERENCES}

Adriano, D.C. 1986. Trace Elements in Terrestrial Environment, New York: Springer -Verlag, ${ }^{r}$ nd ed, 326p.

Al-Awadat, M.A. and Basshy, A. 1990. Pollution and Environmental Protection, Public libraries, University of King Suood, Riad, Sudia Arabic .pp.16-27. (in Arabic).

Al-Barzinjy, A.F. 2000. Gall Stones a Study in Medical Geochemistry, Unpub. M.Sc. Thesis, College of Science, University of Baghdad, Iraq. 97 p . (in Arabic).

Al-Kufaishy, F. M., 1975. Digestion of the Geological Materials, Bull., Sci.,Vol. 16, No. 2, pp. $339-346$.

Al-Sayegh, A.Y. and Al-Taka,A. Sh, 2002. Environmental Pollution, University of Mosul, Iraq. 265p. (in Arabic).

Al-Sayegh, A.Y. and Al-Yazichi, Y.M. 2001. Cars Exhausts Pollution in Mosul City, Rafidain Journal of Science, College of Science, University of Mosul Vol. 12, No.2, pp. 122 -133. (in Arabic).

Al-Sayegh,A.Y. and Al-Mofty, T.M. 1999. Tigris River Recent Sediments Environmen Pollution and Stability Some Chemical Elements Entering Human Body, Rafidain Journal of Science, Vol. 10, No. 2, (in Arabic).

Ali, L. 1987. Industrial Pollution, Dar Al-Kutub Printing and Publish, Mosul University. $335 \mathrm{p}$. (in Arabic).

Emsely, J. 1998. The Elements ( $3^{\text {rd }}$ ed.) Clarendon press, Oxford. London 292p. Faure, G. 1998. Principles and Application of Geochemistry $2^{\text {nd }}$ ed., Prentice - Hall Inc., U.S.A, 600p.

Fergusson, J. E 1982. Inorganic Chemistry and the Earth Chemical Resources, their Extraction Use and Environmental Impact. pp. 334 - 350.

Ismail, S. A. 2004. Atmospheric Pollution and Environmental Effect in Kirkuk Area . $6^{\text {th }}$ Geochemistry International Conference Eskendria, Egypt $12 p$.

Montgomery, C.W. 1997. Environmental Geology ${ }^{7 \text { th }}$ ed Canada, 540 p .

Ommer, M. A. 1987. Environmental Pollution Present and Future Problem, Journal of Science and Future. No. 2, pp. 81 - 89. (in Arabic).

Ommer, M. A. 2000: Environmental Pollution, Wail House, Amman, Jordan 295 p. (in Arabic).

Othman, A. and Sabra, Sh. 1991. Rate of Pollution with Mineral Elements and Air in Damascus City, Environmental Journal of Environmental Searches, Vol.1, pp 20-33. (in Arabic).

Sharaf, A.T. 1986. Environment and Human Health in Medical Geography. Egypt University House, 286p. (in Arabic). 
WHO, 1982: Estimating Human Exposure to Air Pollutants, WHO Offset Publication NO. 69.

WHO, 1979. Environmental Health Criteria 13: Carbon Monoxide Geneva, World Health Organization, $125 \mathrm{p}$.

WHO, 1985. Environmental Pollution Control in Relation to Development, Report a WHO Expert Committee on Housing Health, Technical Report Series TRS, NO, 718 Geneva. 